\title{
Doctor-patient communication in rheumatology: studies of visual and verbal perception using educational booklets and other graphic material
}

\author{
J M H MOLL
}

From the Sheffield Centre for Rheumatic Diseases, Nether Edge Hospital, Sheffield S11 9EL

SUMmary Patients $(n=404)$ with osteoarthrosis and control subjects $(n=233)$ were studied to examine the communicational value of five styles of illustration (cartoon (C), matchstick (M), representational (R), symbolic (S), photographic (P) and two levels of text ('easy', 'hard'), presented as educational booklets about osteoarthrosis. Booklet comprehension was tested with a multiple choice questionnaire (MCQ) scored by two raw score and two, more sensitive, weight-of-evidence methods. Further studies assessed perception of image detail, tone, and colour by ranking, rating, latency, and questionnaire methods. A subgroup was tested psychometrically. The main findings were: $(a)$ pictures in booklets enhance communication; $(b)$ perception of pictorial style depends on its vehicle of presentation, cartoons being most effective in booklets, photographs overall; $(c)$ simplifying text does not significantly enhance communication; $(d)$ certain picture-text 'interactions' appear to increase comprehension (e.g. 'hard' text with 'easy' pictures); $(e)$ several 'endogenous' factors are associated with increased comprehension: 'psychological' (e.g., intelligence, memory, reading skill); 'demographic' (e.g., the young, males, higher social grades, higher educational levels); 'disease' (e.g., longer disease duration, previous information about the disease).

Key words: physician-patient relations, medical communication, psychometrics, graphics, instructional handbooks, visual aids, books-illustrated.

The foundation of all learning consists in representing clearly to the senses sensible objects, so that they can be appreciated easily.

COMENIUS, $1592-70$

The standard of medical care largely depends on satisfactory communications between staff and patient, not least in rheumatology. This is often of an alarmingly poor standard and needs to be improved. ${ }^{1}{ }^{2}$ This is compounded by the fact that hospital patients have poor recall. ${ }^{3} 4$ Failure to achieve satisfactory rapport with patients may lead not only to wasted resources but also to harm or even death. ${ }^{5}$

With these concerns to the fore an interest in doctor-patient communication was fostered in the Rheumatism Research Unit, University of Leeds some years ago and led to publications ${ }^{6}{ }^{7}$ concerned with evaluating and improving the illustrated book-

Accepted for publication 6 August 1985.

Correspondence to Dr J M H Moll. lets of the Arthritis and Rheumatism Councilo (ARC).

These studies raised certain questions about the value of pictures in the booklet format, and these, $\bar{N}$ together with a need to look at textual factors in more detail, led to the studies reported here.

\section{Materials and methods}

MATERI A LS

General plan of studies

The studies were divided into three parts aimed at 0 deriving information about patients' reactions to $\stackrel{\Phi}{\perp}$ visual material, both pictures and words, with $\stackrel{\mathbb{Q}}{\circ}$ particular reference to educational booklets.

Part 1. Patients with osteoarthrosis (OA) $\left(n=\frac{0}{2}\right.$ 
373, male (M) 140, female (F) 233) were each randomly allocated an experimental booklet from a total range of 12 formats. Two to four weeks later subjects were given a multiple choice knowledge testing questionnaire based on the booklets.

Part 2. A subgroup of the above $(n=84, M 24, F$ $60)$ was tested further by means of a battery of psychological tests relating to intelligence, personality, memory, reading ability, and compliance, and also certain perceptual tasks involving picture ranking and rating in the context of the experimental booklets.

Part 3. A small group $(n=30, M 10, F 20)$ of patients with mixed rheumatological diagnosis was examined for perception of certain aspects of detail, tone, and colour in the context of the booklets.

The patients were derived from two centres (Sheffield 300; Leeds 73) and the completion rate (patients willing to participate $\div$ patients available for study $\times 100$ ) was $85.7 \%$.

\section{Control subjects}

Several control groups were involved:

(a) to assess booklet/no booklet difference $(n=31$, M 12, F 19);

(b) to assess patient/non-patient difference $(\mathrm{n}=100, \mathrm{M} \mathrm{41}$, F 59);

(c) to assess knowledge testing sensitivity of questionnaire $(n=41, M 35$, F 6).

\section{Questionnaire}

This was a multiple choice knowledge testing questionnaire based on material about osteoarthrosis covered in the experimental booklets. The questionnaire contained 24 questions with five items in each question (total items $=120$ ). It went through several design and pilot stages before printing, with the aim of producing a balanced research tool of maximal reliability and validity. ${ }^{8}$ The total number of 'Yes' items virtually equalled the 'No' items. The number of questions based on illustrated booklet facts virtually equalled the number based on nonillustrated facts. The definitive questionnaire, a stapled four page document printed in 'Times Roman' was designed to look formal but not formidable, and was prefaced by carefully worded instructions including some in rubric.

\section{Booklets}

The experimental books were on the subject of osteoarthrosis and the text was based on that of the ARC booklet on that subject. In order to provide a reasonable range of picture/text format five styles of illustration (representational, matchstick, cartoon, symbolic, photographic) and two levels of text ('hard'-standard ARC text; and 'easy'-text sim- plified by Flesch's formula ${ }^{9}$ ) were used. In addition, two unillustrated booklets were included to provide a total of 12 formats. All line illustrations were prepared by the author and were aimed at contrasting graphic styles and at comparability of representation of subject matter. Examples are shown in Fig. 1, together with a photographic 'equivalent'. Both the text and the pictures were piloted through several stages to 'weed out' confusions or too difficult material. The booklets were printed by offset lithography on high quality paper in 'Times Roman'. The print was double spaced and set in $11 \mathrm{pt}$ ('Times Bold' $11 \mathrm{pt}$ was used for headings and 'Times Italic' 10 pt for captions) on sheets measuring 7" $\times 4$ " (standard ARC booklet size). The booklets contained 30 pages (15 leaves).

\section{METHODS}

Psychometric and perception tests and tasks

(a) Reading skill-Holburn reading scale. ${ }^{10}$

(b) Intelligence-Peabody picture vocabulary test.

(c) 'De-Americanised' version of original neuroticism and introversion/extraversion scales. Eysenck personality questionnaire. ${ }^{12}$

(d) Long term memory test (simple name and

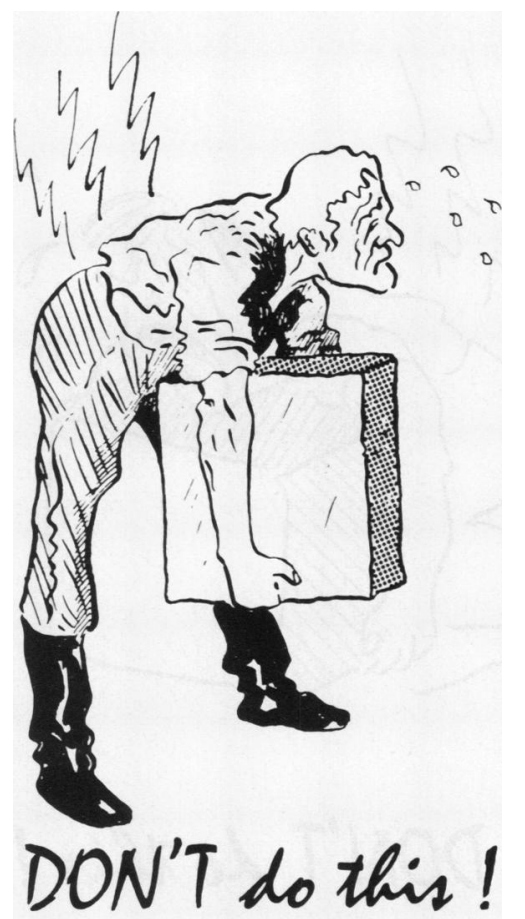

Fig. 1a 


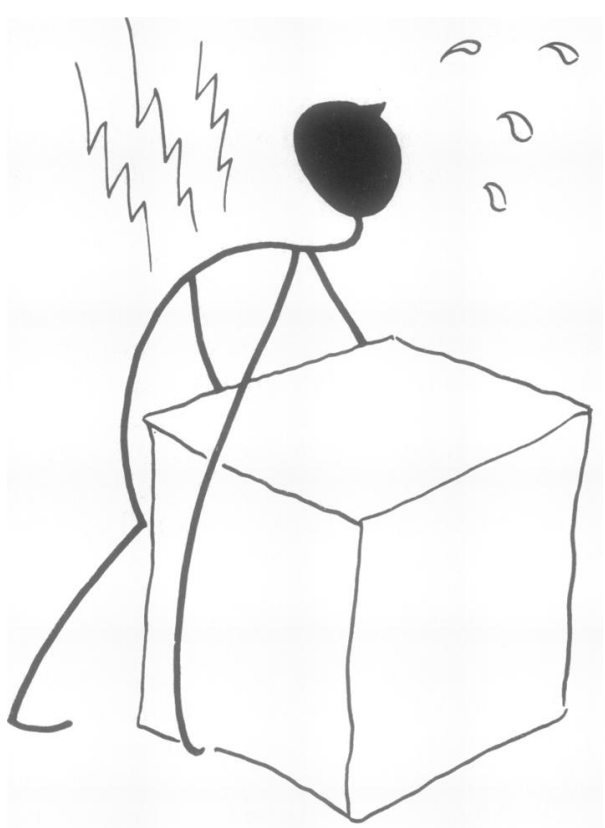

DON'T do this!

Fig. 1b

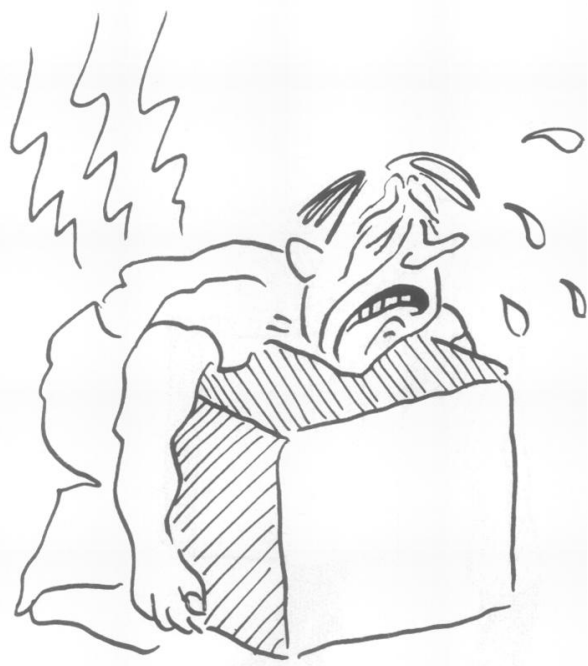

DON'T do this!

Fig. 1c

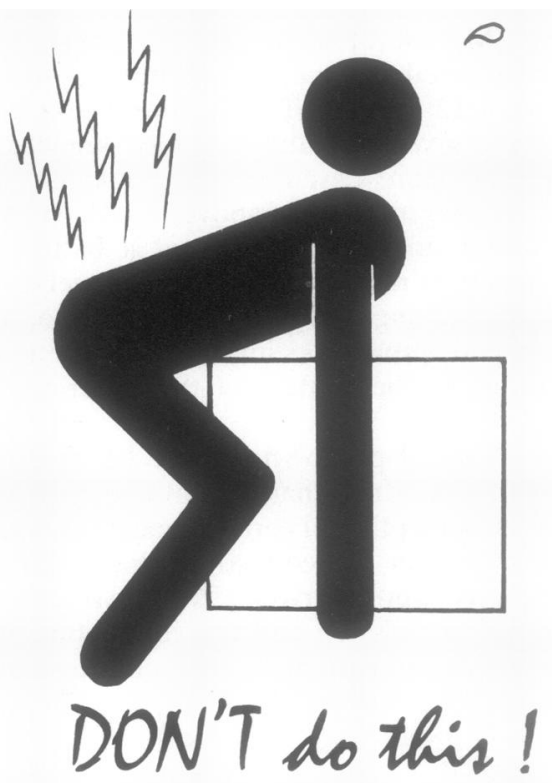

Fig. 1d

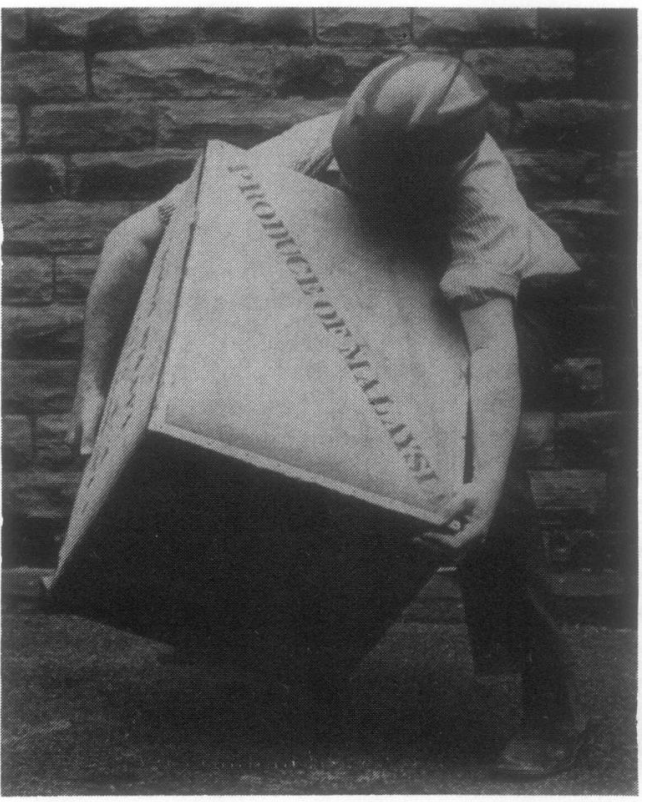

DON'T do this!

Fig. 1e

Fig. 1 Examples of illustrative styles used in the experimental booklets: (a) representational, (b) matchstick, (c) cartoon, (d) symbolic, (e) photographic. 
address test containing 10 elements-numbers and words-and none having any relevance for citizens of Sheffield). Specially designed for survey. Scored simply on basis of correct elements remembered (one point for each).

(e) Compliance matrix. Specially designed for survey, consisting of questions to do with diet, exercises, and medication. Compliance scored 'no', 'sometimes', and 'yes' (carried arbitrarily weighted scores, $0,1,2$ respectively). A catch statement carrying penalty marks was incorporated.

(f) Picture ranking test. Set of cards containing six scenes: ' osis'; 'diagram'; 'obesity', 'causes', 'lifting', 'tablets'. These scenes covered a wide spectrum of graphic devices and also ranged widely through the booklet. Each scene was represented by five different styles (cartoon, matchstick, photographic, representational, symbolic), giving a total of $6 \times 5=30$ pictures. Subjects asked to put cards in order of preference.

(g) Picture rating task. Set of 30 cards described in $(f)$ used. Rating carried out with a plain $10 \mathrm{~cm}$ line visual analogue scale of the type used by Huskisson. ${ }^{13}$ The distance between the mark placed by the subject on the scale line and the 'very good' pole gave a measure of 'goodness'pictorial appreciation.

(h) Inter- and intraimage comparison latencies. These experiments were based on the assumption that reaction times (latencies) to exposure of picture pairs would mirror preferences; a short reaction time implying little doubt because of a clear cut preference; a long reaction time implying indecision associated with less well defined preferences. Times were measured by Heuer 'Trackmaster' stopwatch reading to $1 / 10 \mathrm{~s}$.

(i) Tone/colour tasks. All subjects previously tested with a shortened version of the Ishihara test. ${ }^{14}$

(j) Tone perception task. Series of 13 tonal values ranging from black to white with 11 intervening shades of grey derived from a standard graphic source (Letraset). Subjects asked to put discs (arranged in a circle in random order) in order of increasing lightness. Task timed.

(k) Colour naming task. Series of 10 coloured discs presented in random order-purple/brown/ white/orange/green/grey/red/blue/black/yellow. Subjects asked to name colours and nearest interpretation recorded (e.g., 'bluish green' recorded as green). Task not timed.

(l) Colour preference task. Series of 16 coloured discs. Subjects asked to remove discs in the order in which they liked them best. Only first 10 required.

(m) Colour-pair comparisons. A series of 10 double colour discs presented to subjects who were asked (i) which colour of each pair preferred and (ii) which colour pair preferred.

(n) Colour-triple comparisons. A series of 10 triple colour discs presented to subjects who were asked (i) which colour in each triple preferred and (ii) which colour triple preferred.

(o) Picture preference questionnaire. Designed to cross check with the detail/tone/colour tasks and to assess preferences concerning-humorous $v$ serious pictures, photographs $v$ line drawings, and pictures with captions $v$ pictures without captions.

\section{Questionnaire scoring procedures}

(a) Raw analysis. Two methods used to obtain raw scores (because of present controversy about raw scoring): $0 /+1$ system $^{15}{ }^{16}$-one mark awarded for each correct response, no marks for incorrect responses or statements not attempted. $-1 / 0 /+1$ system - one mark awarded for each correct response, no marks for non-attempts, and -1 for each incorrect response.

(b) Weight-of-evidence analysis. This approach designed to counter the effect of guessing and provide a measure of the accuracy with which questionnaires were answered. Using special tables raw scores (obtained by $0 /+1$ ) were converted to 'creds' (the negative logarithm of the probability that the examinee is not guessing). In the study creds scores were obtained by the methods of both Bevans $^{17}$ and Good. ${ }^{18}$

\section{Computometric and statistical methods}

The University of Sheffield ICL 1900 Implementation-Release 2 computing system was used. Statistical data were derived from programs based on the statistical package for the social sciencesversion $5 \cdot 01 .^{19}$ The printout included sum, mean, mode, standard deviation, variance, standard error of mean, percentage, $n$ value, and 'Anova' (analysis of variance) tables showing sum of squares of freedom, mean square, Snedecor's ' $F$ '20 and Student's ' $t$ '21 values. Correlations were expressed by Spearman's rank correlation coefficient $(r)$.

\section{Results}

STUDIES TO EXAMINE THE EFFECTS OF BOOKLET PICTORIALANDTEXTUAL FACTORS

Do booklets improve recall?

Table 1 shows that patients exposed to booklets scored significantly higher marks (by means of all four scoring methods) than control subjects not exposed to a booklet.

Do pictures add to words?

The assumption that pictures add to words in 
Table 1 Do booklets improve recall?

\begin{tabular}{|c|c|c|c|c|c|}
\hline \multirow[t]{2}{*}{ Group } & \multirow[t]{2}{*}{$n$} & \multicolumn{4}{|l|}{ Scores } \\
\hline & & $0 /+1$ & $-1 / 0 /+1$ & Bevans & Good \\
\hline $\begin{array}{l}\text { OA patients not exposed to booklet } \\
\text { OA patients exposed to booklet } \\
\text { Significance of difference (p) }\end{array}$ & $\begin{array}{r}31 \\
373\end{array}$ & $\begin{array}{l}54.4( \pm 2.69) \\
63.5( \pm 0.75) \\
=0.002\end{array}$ & $\begin{array}{l}27.2( \pm 3.09) \\
39.2( \pm 1.06) \\
=0.001\end{array}$ & $\begin{array}{l}40.3( \pm 6.57) \\
69 \cdot 5( \pm 2 \cdot 79) \\
<0.001\end{array}$ & $\begin{array}{l}35 \cdot 5( \pm 6.35) \\
63 \cdot 7( \pm 2 \cdot 69) \\
<0 \cdot 001\end{array}$ \\
\hline
\end{tabular}

Values are mean $\pm S D$.

conveying medical information was supported by the following:

(a) Exposure to illustrated booklets led to higher questionnaire scores than exposure to unillustrated booklets, but the difference was not statistically significant.

(b) Exposure to certain types of booklet, such as the cartoon- and matchstick-illustrated booklets (associated with standard text) led to significantly higher questionnaire scores $(\mathrm{p}<0.05$, Students' $t$ test) when compared with subjects exposed to unillustrated booklets with comparable text.

(c) Analysis of individual questionnaire item scores (regardless of whether based on illustrated, unillustrated, or unrepresented facts) showed that subjects who had read an illustrated booklet or achieved more scores that were significantly signifi- $\omega$ cant than subjects who had read either an unillus- $\vec{\theta}$ trated booklet or no booklet.

(d) The picture preference questionnaire showed that $70 \%$ of subjects preferred reading material with rather than without illustrations $(p=0.028)$.

Are some styles of illustrations more effective than others?

Some styles of illustration were found to be more

Table 2 Studies of factors affecting recall of medical facts

\begin{tabular}{|c|c|c|c|}
\hline Nature of enquiry & $n$ & Procedure & Results \\
\hline $\begin{array}{l}\text { Is recall better for some facts } \\
\text { than for others? }\end{array}$ & 373 & $\begin{array}{l}\text { MCQ analysed according to item } \\
\text { type: (see text) } \\
\text { - causes of discase } \\
\text { - nature of discase } \\
\text { - clinical features } \\
\text { - -sclf help features } \\
\text { - treatment aspects }\end{array}$ & $\begin{array}{l}\text { Types of facts recalled in the order: } \\
\text { 1. Self help features } \\
\text { 2. Clinical features } \\
\text { 3. Treatment aspects } \\
\text { 4. Causes of the discasc } \\
\text { 5. Nature of the disease } \\
\text { (Pictorial style may differentially influence } \\
\text { fact recall) }\end{array}$ \\
\hline
\end{tabular}

Is recall related to order of presentation of textual material?

Is recall related to their degrec of 373 textual repetition?

Is recall related to differences in 310 format of the graphic image?
MCO analysed according to degrec of booklet statement repetition: -not mentioned (distractors)

-repeated $\times 1$

-repcated $\times 3$

-repeated $\times 3$ or morc

MCQ analysed according to format of booklet graphics:

-without verbal message

-with legends

一with slogans

-with captions

-with legends and captions (a) 'Recency' rather than 'primacy' was observed (later facts remembered best)

(b) Relationship between order and recall was significant for illustrated facts $(r=0.4101$ D $p=0.005$ ), but not for unillustrated facts $(r=0 \cdot 1905, p=0 \cdot 058)$

(a) Recall in general not convincingly related to repetition

(b) However, a significant difference $(p<0.05)$ was found between the categorics 'no mention' and ' $\times 1$ (or more) mention'

The two formats containing legends (hand lettered) scored significantly $(p<0.05)$ less than the other three formats 
Table 3 Studies of detail, tone, and colour perception*

\begin{tabular}{|c|c|c|c|}
\hline Area of study & $\begin{array}{l}\text { No of } \\
\text { patients }\end{array}$ & Procedure & Results \\
\hline Image detail & 30 & $\begin{array}{l}\text { Twelve variants of 'lifting scene', } \\
\text { cach paired with control (see text) }\end{array}$ & $\begin{array}{l}\text { (a) } 33.6 \% \text { failed to discriminate variant from control } \\
\text { (b) 'Eccentric', 'reversed', and 'tinted' variants } \\
\text { provided most difficulty } \\
\text { (c) One third failed to judge identical pair as identical } \\
\text { (d) Image position and size created more difficulty } \\
\text { than outline and content } \\
\text { (e) Inverse relationship }(\mathrm{r}=-0 \cdot 4876, \mathrm{p}=0 \cdot 045) \\
\text { between correct assessment and reaction time }\end{array}$ \\
\hline Tonal shades & 30 & $\begin{array}{l}\text { Thirteen discs, each with a different } \\
\text { tonal shade (see text) }\end{array}$ & $\begin{array}{l}\text { (a) Most subjects achieved roughly correct absolute } \\
\text { order }(\mathrm{r}>0 \cdot 8, \mathrm{p}<0 \cdot 002) \\
\text { (b) Failing this most achieved correct relative order } \\
\text { (c) No relationship between task time and accuracy }\end{array}$ \\
\hline Colour naming & 30 & $\begin{array}{l}\text { Ten cards, each tinted with a } \\
\text { conventional colour. All subjects } \\
\text { had normal colour vision (Ishihara's test) }\end{array}$ & $100 \%$ accuracy achieved by all subjects \\
\hline $\begin{array}{l}\text { Colour preference: } \\
\text { Colour } v \text { black } \\
\text { and white }\end{array}$ & 30 & $\begin{array}{l}\text { Picture preference questionnaire: 'Do } \\
\text { you prefer reading material with } \\
\text { black and white or colour pictures?' }\end{array}$ & $\begin{array}{l}90 \% \text { preferred colour to black and white pictures } \\
(p<0 \cdot 00001)\end{array}$ \\
\hline Single colours & 30 & Sixteen coloured cards (sec text) & $\begin{array}{l}\text { Dark blue and orange were equally the most popular } \\
\text { colours, being ranked first preference by } 20 \% \\
\text { of subjects }\end{array}$ \\
\hline Colour pairs & 30 & $\begin{array}{l}\text { Ten discs, each tinted on one side with } \\
\text { two colours of equal area ( } \mathrm{sec} \text { text) }\end{array}$ & $\begin{array}{l}\text { Colour preferred in each pair: green }(59 \cdot 18 \%) \text {; } \\
\text { blue }(55 \cdot 85 \%) \text {; yellow }(55 \cdot 83 \%) \text {. } \\
\text { Colour pair preferred: brown-yellow }(30 \%) \text {; } \\
\text { yellow-green }(16 \cdot 7 \%) \text {; yellow-blue, red-yellow, } \\
\text { blue-brown (each } 10 \%)\end{array}$ \\
\hline Colour triples & 30 & $\begin{array}{l}\text { Ten discs, each tinted on one side with } \\
\text { three colours of equal area (see text) }\end{array}$ & $\begin{array}{l}\text { Colour preferred in each triple: yellow }(40 \cdot 0 \%) \text {; } \\
\text { green }(37 \cdot 95 \%) \text {; red }(31 \cdot 85 \%) \text {. Colour triple } \\
\text { preferred: brown-yellow-green }(23 \cdot 3 \%) ; \text { green-red- } \\
\text { yellow }(23 \cdot 3 \%) \text {; yellow-blue-green }(20 \cdot 0 \%)\end{array}$ \\
\hline
\end{tabular}

\footnotetext{
${ }^{*}$ No significant differences between patients $(n=30, M 10, F 20)$ and a control group of $10(M 3, F 7)$ healthy subjects.
}

effective than others, and the variation depended on the way in which the pictorial material was presented (i.e., in booklets or on cards).

(a) The booklet study. All four scoring methods showed superior scores in the group exposed to cartoons. The 'matchstick' group was second and the 'photographic' group third. (The ranking of the other styles depended on the scoring system used.)

(b) The ranking study. In terms of most first places, superior scores were for symbolic drawings, followed in order by cartoons, photographs, representational drawings, and matchstick figures. (In terms of at least last places, matchstick figures scored best, followed in order by photographs, cartoons, representational drawings, and symbolic drawings.) (c) The rating study. Little difference between styles was shown, but in rank order they were: photographic, representational, symbolic, cartoon, matchstick.

(d) The latency study. Scoring according to percentage preferences was in the following order: photographic, representational, symbolic, cartoon, matchstick. (Latencies showed no significant difference between styles of illustration.)

(e) Picture preference questionnaire. This showed no significant difference $(p>0 \cdot 25)$ between preferences for funny and serious pictures. A significant difference $(p<0.01)$ supported a preference for photographs, as opposed to line drawings.

(f) Overall ranking of styles from methods (a)$(e)$ : 1. photographic, 2. symbolic, 3. cartoon, 4 . representational, 5. matchstick. 
Table 4 Psychological factors $(n=10)$

\begin{tabular}{|c|c|c|c|c|}
\hline \multirow[t]{2}{*}{ Variable } & \multirow[t]{2}{*}{$n$} & \multirow[t]{2}{*}{ General comment } & \multicolumn{2}{|c|}{ Relationship with post-test score $\overline{\mathrm{S}}$} \\
\hline & & & $r^{*}$ or $t^{*}$ & $p$ \\
\hline $\begin{array}{l}\text { Intelligence (Peabody picture } \\
\text { vocabulary test) }\end{array}$ & 84 & $\begin{array}{l}\text { Significant correlation between questionnaire score } \\
\text { and level of intelligence }\end{array}$ & $\begin{array}{l}0 \cdot 364 \\
0 \cdot 478 \\
0 \cdot 454 \\
0 \cdot 452\end{array}$ & $\begin{array}{l}<0 \cdot 001 \\
<0 \cdot 001 \\
<0 \cdot 001 \\
<0 \cdot 001\end{array}$ \\
\hline $\begin{array}{l}\text { Personality (Eysenck's } \\
\text { neuroticism and introversion/ } \\
\text { extraversion scales) }\end{array}$ & 84 & $\begin{array}{l}\text { (a) Significant negative correlation between } \\
\text { questionnaire score and neuroticism } \\
\text { (b) No significant correlation between questionnaire } \\
\text { score and introversion/extraversion }\end{array}$ & $\begin{array}{r}-0 \cdot 114 \\
-0 \cdot 178 \\
-0 \cdot 189 \\
-0 \cdot 187 \\
0 \cdot 035 \\
0 \cdot 017 \\
-0 \cdot 007 \\
-0 \cdot 007\end{array}$ & $\begin{array}{l}0 \cdot 150 \\
0 \cdot 053 \\
0 \cdot 043 \\
0 \cdot 044 \\
0 \cdot 375 \\
0.438 \\
0.475 \\
0.475\end{array}$ \\
\hline $\begin{array}{l}\text { Long term memory (simple } \\
\text { test devised for the study) }\end{array}$ & 84 & $\begin{array}{l}\text { Significant positive correlation between questionnaire } \\
\text { and long term memory score }\end{array}$ & $\begin{array}{l}0 \cdot 205 \\
0 \cdot 159 \\
0 \cdot 163 \\
0 \cdot 164\end{array}$ & $\begin{array}{l}0 \cdot 031 \\
0 \cdot 075 \\
0 \cdot 069 \\
0 \cdot 068\end{array}$ \\
\hline $\begin{array}{l}\text { Reading skill (Holburn } \\
\text { reading scale) }\end{array}$ & 84 & $\begin{array}{l}\text { Significant positive correlation between questionnaire } \\
\text { score and reading skill score }\end{array}$ & $\begin{array}{l}0 \cdot 349 \\
0 \cdot 472 \\
0 \cdot 423 \\
0 \cdot 422\end{array}$ & $\begin{array}{l}<0 \cdot 001 \\
<0 \cdot 001 \\
<0 \cdot 001 \\
<0 \cdot 001\end{array}$ \\
\hline $\begin{array}{l}\text { Compliance (compliance matrix } \\
\text { devised for the study) }\end{array}$ & 84 & $\begin{array}{l}\text { No significant correlation between questionnaire } \\
\text { score and compliance score }\end{array}$ & $\begin{array}{r}0 \cdot 053 \\
-0 \cdot 009 \\
0 \cdot 032 \\
0 \cdot 032\end{array}$ & $\begin{array}{l}0 \cdot 315 \\
0 \cdot 469 \\
0 \cdot 385 \\
0 \cdot 385\end{array}$ \\
\hline $\begin{array}{l}\text { Attitudes towards reading } \\
\text { material }\end{array}$ & 371 & $\begin{array}{l}\text { No significant correlation between questionnaire } \\
\text { score and 'enjoyable/not enjoyable' scores or } \\
\text { 'helpful/not helpful' scores }\end{array}$ & $\begin{array}{l}t=0 \cdot 915 \\
t=0 \cdot 018 \\
t=0 \cdot 018 \\
t=0 \cdot 233 \\
t=0 \cdot 005 \\
t=0 \cdot 819 \\
t=0 \cdot 344 \\
t=0 \cdot 335\end{array}$ & $\begin{array}{l}0.361 \\
0.986 \\
0.986 \\
0 \cdot 816 \\
0.996 \\
0.413 \\
0.731 \\
0.738\end{array}$ \\
\hline Spontaneous comments & 371 & $\begin{array}{l}\text { (a) Significantly higher questionnaire scores among } \\
\text { subjects who made spontaneous comments (of } \\
\text { whatever type) } \\
\text { (b) Booklets generating most spontaneous comments } \\
\text { were C, P, M. S. R and unillustrated } \\
\text { stimulated fewer comments }\end{array}$ & $\begin{array}{l}t=3 \cdot 295 \\
t=2 \cdot 807 \\
t=2 \cdot 161 \\
t=2 \cdot 173 \\
\text { Not safely } \\
\text { analysable }\end{array}$ & $\begin{array}{l}0 \cdot 001 \\
0 \cdot 005 \\
0 \cdot 031 \\
0 \cdot 030\end{array}$ \\
\hline $\begin{array}{l}\text { 'Reinforcement' (number of } \\
\text { times booklet read) }\end{array}$ & 371 & $\begin{array}{l}\text { (a) Analysis of variance showed significant trend } \\
\text { pointing to increasing scores with increasing } \\
\text { reinforcement (peaking at four times read) }\end{array}$ & & $<0 \cdot 001$ \\
\hline & & $\begin{array}{l}\text { (b) Correlation study showed relationship to be } \\
\text { significant though not strong }\end{array}$ & $\begin{array}{l}0 \cdot 1413 \\
0 \cdot 1340 \\
0 \cdot 1247 \\
0 \cdot 1246\end{array}$ & $\begin{array}{l}0 \cdot 003 \\
0 \cdot 005 \\
0 \cdot 008 \\
0 \cdot 008\end{array}$ \\
\hline $\begin{array}{l}\text { Booklet exposure- } \\
\text { questionnaire test interval }\end{array}$ & 371 & $\begin{array}{l}\text { Weak, although significant correlations pointed to } \\
\text { higher test scores with lower reading test intervals }\end{array}$ & $\begin{array}{l}-0 \cdot 156 \\
-0 \cdot 134 \\
-0 \cdot 154 \\
-0 \cdot 155\end{array}$ & $\begin{array}{l}<0 \cdot 05 \\
\sim 0 \cdot 05 \\
<0 \cdot 05 \\
<0 \cdot 05\end{array}$ \\
\hline $\begin{array}{l}\text { Questionnaire completion } \\
\text { time }\end{array}$ & 306 & $\begin{array}{l}\text { Slight indication that the shorter the time to } \\
\text { complete the questionnaire the better the score }\end{array}$ & $\begin{array}{r}0 \cdot 001 \\
-0 \cdot 145 \\
-0 \cdot 149 \\
-0 \cdot 015\end{array}$ & $\begin{array}{l}0.491 \\
0.006 \\
0 \cdot 004 \\
0.005\end{array}$ \\
\hline
\end{tabular}


Table 5 Correlations between psychological attributes

\begin{tabular}{|c|c|c|c|c|c|c|}
\hline & Reading ability & Long term memory & Intelligence & Neuroticism & $\begin{array}{l}\text { Introversion/ } \\
\text { extraversion }\end{array}$ & Compliance \\
\hline Reading ability & - & $\begin{array}{l}r=0.1696 \\
p=0.062\end{array}$ & $\begin{array}{l}r=0.5666 \\
p=0.001\end{array}$ & $\begin{array}{l}r=-0.1790 \\
p=0.052\end{array}$ & $\begin{array}{l}r=0.0790 \\
p=0.0237\end{array}$ & $\begin{array}{l}r=0.0178 \\
p=0.436\end{array}$ \\
\hline Long term memory & - & - & $\begin{array}{l}r=0.1743 \\
p=0.056\end{array}$ & $\begin{array}{l}r=0.0082 \\
p=0.471\end{array}$ & $\begin{array}{l}r=0.1325 \\
p=0.115\end{array}$ & $\begin{array}{l}r=0.0016 \\
p=0.494\end{array}$ \\
\hline Intelligence & - & - & - & $\begin{array}{l}r=-0 \cdot 2245 \\
p=0 \cdot 020\end{array}$ & $\begin{array}{l}r=-0.0620 \\
p=0.288\end{array}$ & $\begin{array}{l}\mathrm{r}=-0 \cdot 0580 \\
\mathrm{p}=0 \cdot 300\end{array}$ \\
\hline Neuroticism & - & - & - & - & $\begin{array}{l}r=-0.3107 \\
p=0.002\end{array}$ & $\begin{array}{l}\mathrm{r}=-0 \cdot 1235 \\
\mathrm{p}=0.132\end{array}$ \\
\hline $\begin{array}{l}\text { Introversion/ } \\
\text { extraversion }\end{array}$ & - & - & - & - & - & $\begin{array}{l}r=0.1993 \\
p=0.035\end{array}$ \\
\hline Compliance & - & - & - & - & - & - \\
\hline
\end{tabular}

Do captions alter preferences for pictures?

The differences between the series with and without captions (some of them statistically significant) were thought to reflect experimental 'set' rather than true perceptual differences.

Does improving textual readability enhance recall? In general there were no statistical differences between the 'hard' and 'easy' groups. However, the results suggested an interaction between 'hard' text and 'easy' pictures, and vice versa.

STUDIES OFFACTORS AFFECTING RECALL OF MEDICAL FACTS

The results of certain inquiries into booklet factors and their effect on recall are summarised in Table 2.

STUDIES TO EXAMINE PERCEPTION OF DETAIL, TONE, AND COLOUR

The results of these studies are shown in Table 3.

STUDIES OF 'ENDOGENOUS' FACTORS Analysis of certain groups of endogenous factors of direct or indirect relevance to educational booklet comprehension is subdivided and tabulated as follows: psychological factors (Table 4), correlations between psychological factors (Table 5), physiological factors (Table 6), personal factors (Table 7).

QUESTIONNAIRE AND SCORING FACTORS The questionnaire in pilot and post-test studies showed reasonable reliability, validity, and discriminatory power (Table 8). The weight-ofevidence methods proved more sensitive than the raw scoring methods, but there was a high degree of correlation $(\mathrm{r}=0 \cdot 8015$ to $0.9999, \mathrm{p}=0 \cdot 001)$ between all four methods. The $-1 / 0 /+1$ method had an intermediate place between the $0 /+1$ raw score method and the weight-of-evidence methods.

\section{Discussion}

The material reported here comprises a summary of a series of studies. For convenience of discussion they will be divided accordingly into three sections: the effects of booklet pictorial and textual factors; the perception of detail, tone, and colours; and the 'endogenous' factors in rheumatological communication.

STUDIES TO EXAMINE THE EFFECTS OF BOOKLET PICTORIAL AND TEXTUAL

F A C T OR S.

Overall conclusions from these studies are:

(a) Instructional booklets, whether written in 'easy' or 'hard' style, or whether illustrated or unillustrated, improve recall of medical facts in a rheumatological context.

(b) Illustrated booklets are more effective than

Table 6 Physiological factors $(n=3)$

\begin{tabular}{lllll}
\hline Variable & $n$ & \multicolumn{2}{l}{ Relation with post-test score } & \\
\cline { 2 - 4 } & & $F$ & $p$ & Test \\
\hline Eye dominance & 30 & $1 \cdot 178-0.009$ & $>0.05$ & $\mathrm{~F}^{*}$ \\
Handedness & 30 & $0 \cdot 222-0.001$ & $>0.05$ & $\mathrm{~F}$ \\
Colour blindness & 30 & Not measurable & & - \\
\hline
\end{tabular}

${ }^{*}$ Snedecor's F test. 
Table 7 Personal factors $(n=10)$

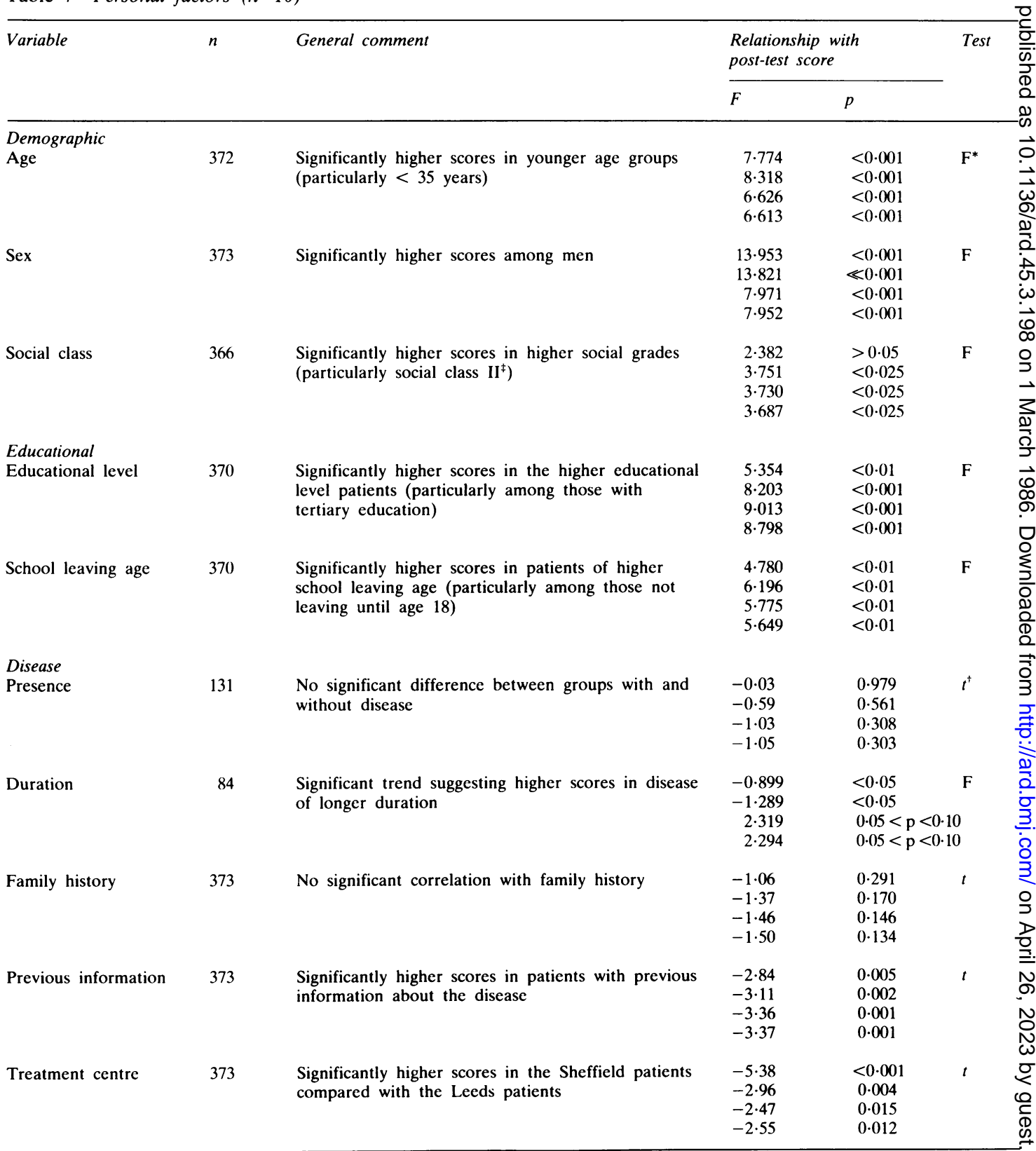

* Snedecor's $\mathrm{F}$ test.

+ Student's $t$ test.

$\ddagger$ No subjects in social class I. 
Table 8 Questionnaire analysis

\begin{tabular}{|c|c|c|}
\hline $\begin{array}{l}\text { Type of } \\
\text { analysis }\end{array}$ & Aim & Result/comment \\
\hline Pilot studies & $\begin{array}{l}\text { To reduce mean score to an acceptable level } \\
\text { by increasing plausibility of distractors } \\
\text { (false statements) }\end{array}$ & $\begin{array}{l}\text { 1st }-84 \cdot 1 \% \\
2 \text { nd }-69 \cdot 0 \% \\
\text { 3rd }-62 \cdot 0 \% \\
\text { 4th- } 59 \cdot 6 \% \\
\text { Satisfactory reduction (towards 'ideal' } 50 \% \text { ) }\end{array}$ \\
\hline Reliability & $\begin{array}{l}\text { To test ability of questionnaire to achieve } \\
\text { reproducible results by internal checks and } \\
\text { test-retest analysis }\end{array}$ & $\begin{array}{l}\text { Reliability confirmed by both approaches. } \\
\text { Test-retest difference } 10 \cdot 6 \%\end{array}$ \\
\hline Validity & $\begin{array}{l}\text { To test whether questionnaire measures what } \\
\text { it is supposed to measure }\end{array}$ & $\begin{array}{l}\text { Reasonable gradation of performance in groups with varying } \\
\text { rheumatological knowledge and experience confirmed validity: } \\
\text { Consultant rheumatologists } 91 \% \\
\text { General practitioners } 83 \% \\
\text { Medical students } 79 \% \\
\text { Qualified nurses } 76 \% \\
\text { Student nurses } 78 \% \\
\text { Dental students } 65 \% \\
\text { Patients exposed to booklet } 64 \% \\
\text { Patients not exposed to booklet } 54 \% \\
\text { Non-medical healthy controls } 55 \%\end{array}$ \\
\hline $\begin{array}{l}\text { Discriminatory } \\
\text { power }\end{array}$ & $\begin{array}{l}\text { To check that questions and items are not } \\
\text { too easy, not too hard, and not too 'neutral' } \\
\text { due to bad wording }\end{array}$ & $\begin{array}{l}\text { Anderson's method }{ }^{15} \text { : } \\
\text { correlations between individual questions (as opposed to items) } \\
>\mathrm{r}-0 \cdot 3 \text {, the 'good' discrimination level } \\
\text { Fieller's modification (personal communication): } \\
\text { general pattern satisfactory, many questions } \\
\text { achieving high discrimination values (Snedecor } \mathrm{F} \text { values with } \\
\mathrm{p}<0 \cdot 001 \text { ) }\end{array}$ \\
\hline
\end{tabular}

unillustrated booklets. This finding is supported by the work of Booker, ${ }^{22}$ who also showed that pictures are important for the speed of learning, whereas print is important for accuracy. Another study of bearing on the present work is that of Hamilton, ${ }^{23}$ who found that flat, moving, or still pictures score better than purely textual, oral, 'audio', and three dimensional presentations of educational material.

(c) The preferred style of illustration varied according to the design of the presentation. However, overall, photographs emerged as the most generally favoured style, followed in order by symbolic drawings, cartoons, representational drawings, and matchstick images. Cartoons scored particularly well when presented as booklet illustrations. Preference for photographs fits with the thinking vogue of the era in which we live-an era heavily influenced by a respect for and an appreciation of machine rather than man made articles. Photographs also saturate our environment both in static and 'movie' forms, and books, magazines, newspapers, television, and cinema largely depend on this familiar mode for their effects. For a visually relatively unsophisticated population such 'environmental programming' may be influential. The emergence of the cartoon as the preferred style in the context of booklet presentation can be interpreted in various ways: a reflection of the general popularity of cartoons in everyday life; an effect of assuaging anxiety in 'trivialising' the significance of rheumatic ailments; a 'warming' effect in promoting relaxation in the doctor-patient relationship. It could also be argued that cartoons might work in the opposite direction in generating irritation among patients who interpret cartoons as being inappropriate in a field that is far from humorous.

(d) Improving textual readability did not lead to improvement of recall. Several previous studies have been concerned with improving the readability of texts (e.g. employee handbooks and pamphletsDavis and Hopkins ${ }^{24}$; Farr $^{25}$; Carlucci ${ }^{26}$; children's textbooks-Faison ${ }^{27}$; psychology texts-Ogdon ${ }^{28}$; Anderson $^{29}$ ), but few have been concerned with evaluating the results of such 'improvements'. A study of relevance here is that of Ley $\mathrm{el}^{30}$ who examined comprehensibility of $x$-ray leaflets using Flesch's principles, as in this study. These workers found increased recall in one type of leaflet (containing cholecystogram details) but not with another (leaflet on barium studies).

(e) The apparent interplay between textual difficulty and style of textual illustration is interesting 
and previously undocumented. Further work is needed to examine this effect in more detail. Interpretation of this picture/text interaction could relate to perceptive arousal. For example, when the style of illustration is relatively 'easy' from the point of view of interpretability and familiarity a 'hard' text may be necessary to maintain an optimal level of arousal.

(f) Analysis of the relative recall of booklet facts according to their medical significance, order of presentation, and textual repetition provided data that may be useful in the general planning of future educational booklets. The fact that recall is better for some medical facts (particularly 'self help' and 'clinical features') has been found by others. ${ }^{3} 43132$ The finding that 'primacy' rather than 'recency' is related to improved recall of medical facts (particularly when the facts are illustrated) is at variance with a study by Ley and Spelman ${ }^{1}$ and with one by the present author. ${ }^{6}$ Either results can be 'justified' psychologically-'primacy' being related to the impact of first impressions, 'recency' to memory delay with time. The finding that repetition of facts (especially with higher orders of repetition) was not convincingly related to recall militates against general assumptions and evidence in the field of memory and learning in animal and human (nonmedical) settings. However, this area needs further study as it could be argued that facts mentioned only once were mentioned only once because they were 'easier' to understand than facts mentioned twice or more.

STUDIES TO EXAMINE PERCEPTION OF

DETAIL, TONE, AND COLOUR

The visual perception of patients differed in no significant way from that of healthy controls and varied according to the nature of the task. Thus reasonable competence was shown in correct identification of tonal shades and colours, but some difficulty was found in differentiating between image details (particularly positional and size differences). The studies based on colour showed preferences that could be of relevance to future booklet design (e.g., for covers and textual illustrations). Dark blue and, slightly less so, orange were high preference colours when used in isolation. Yellow, on the other hand, though not popular when viewed in isolation, was probably useful in creating an arousal effect when presented with other colours.

STUDIES OF 'ENDOGENOUS' FACTORS IN RHEUMATOLOGICAL COMMUNICATION

Recall of booklet material was found to be significantly correlated with several psychological and personal factors. In the design and evaluation of future booklets, importance should be directed to $\frac{\mathrm{N}}{\mathrm{n}}$.

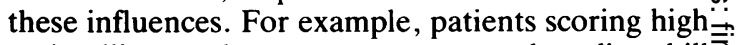
on intelligence, long term memory, and reading skillos are likely to score well on booklet comprehension. Improved scores are also more likely the more timeso a booklet is read and the shorter the interval $\frac{\bar{s}}{\sigma}$ between booklet exposure and testing. On the other $\stackrel{\mathbb{\Omega}}{\Omega}$ hand, a decreased performance can be expected ing the neurotic and in those who take longer to complete their questionnaire. No correlation was.. found between booklet performance and com- $\vec{\omega}$ pliance rating.

Allowances should also be made for certain 'personal' factors (demographic, educational, and ${ }_{\perp}^{\circ}$ disease factors). Thus higher scores on booklet comprehension can be expected in younger patients, in males, and in those of higher social grade..$\infty$ Superior results are also more likely in those ofo higher educational level and of higher school leaving age. Certain disease factors are also positively andz significantly correlated with booklet comprehen- $\frac{0}{2}$ sion. These include longer disease duration and? previous information about the disease.

Other workers have drawn attention to the importance of some of these endogenous factors, though in general little work has been done in thiso sphere, except in that relating to age. Thus long term memory ${ }^{33}$ and intellectual function ${ }^{34}$ decrease with age; although Birren and Morrison ${ }^{35}$ stressed $^{\circ}$ that the effect of educational level supersedes that of age, in test performance.

In conclusion, these studies have shown that illustrated educational booklets in the field of rheumatology exert a significant communicationa? effect. The data reported therefore provide objecs tive support for the current policy by various rheumatology organisations (e.g. ARC, American Rheumatism Association) of using instructionalo booklets in this field.

The studies were generously supported by a research grant from? the Arthritis and Rheumatism Council and led to a PhD (Univer sity of Leeds). I am especially grateful to Mrs P Drake for data‥ collection and for technical help; to Drs H G Bevans and N R h Fieller for statistical advice; to $\mathrm{Mr}$ P R F Clarke, Dr P Ley Professor P B Warr, and Mrs S McLaren for psychometric advicen to Mrs Robbie Hopkins for collecting Leeds data; to the Medica Illustration Unit, Northern General Hospital, Sheffield; and tow Professors V Wright and H Gwynne Jones for helpful discussions.

References

1 Ley P, Spelman M S. Communicating with the patient. London: Staples Press, 1967

2 Egbert L D, Battit G E, Welch C E, Bartlett M K. Reduction D of postoperative pain by encouragement and instruction of patients. A study of doctor-patient rapport. $N$ Engl J Med 1964 , 270: $825-7$.

3 Ley P, Spelman M S. Communications in an out-patient setting Br J Soc Clin Psychol 1965; 4: 114-6. 
4 Joyce C R B, Caple G, Mason M, Reynolds E, Mathews J A. Quantitative study of doctor-patient communication. $Q J$ Med 1969; 38: 183-94.

5 Medical News. $\mathrm{Br}$ Med $J$ 1978; ii: 1796

6 Moll J M H, Wright V. Evaluation of the Arthritis and Rheumatism Council handbook on gout. An objective study of doctor-patient communication. Ann Rheum Dis 1972; 31: 405-11.

7 Moll J M H, Wright V, Jeffrey M R, Goode J D, Humberstone $P \mathbf{M}$. The cartoon in doctor-patient communication. Further study of the Arthritis and Rheumatism Council handbook on gout. Ann Rheum Dis 1977; 36: 225-31.

8 Oppenheim A N. Questionnaire design and attitude measurement. London: Heinemann, 1966.

9 Flesch R F. How to test readability. New York: Harper and Row, 1951.

10 Watts A F. The Holburn reading scale. London: Harrap, 1948: 3-8.

11 Dunn L M. Expanded manual for the Peabody picture vocabulary test. Minnesota: American Guidance Service, 1965.

12 Eysenck H J, Eysenck S B G. Manual of the Eysenck personality questionnaire. London: Hodder and Stoughton, 1965.

13 Huskisson E C. Measurement of pain. Lancet 1974; ii: 1127-38.

14 Ishihara S. The series of plates designed as a test for colourblindness. 38 plates ed. Tokyo: Kanehara Shuppan, 1969.

15 Anderson J. The multiple choice questionnaire in medicine. Tunbridge Wells: Pitman, 1976.

16 Fleming P R, Sanderson P H, Stokes J F, Walton H J. Examinations in medicine. Edinburgh: Churchill Livingstone, 1976.

17 Bevans H G. Confidence (probability) scoring for the standard progressive matrices and the advanced matrices. British Psychological Society, Annual Conference. Swansea, 1966.

18 Good I J. Weighing evidence. In: Probability and the weighting of evidence. London: Griffin, 1950: 62-75.
19 Nie N, Bent D, Hull C. Statistical package for the social sciences. New York: McGraw-Hill, 1970.

20 Snedecor G W. Statistical methods. 4th ed. Ames, Iowa: Iowa State College Press, 1946.

21 Siegel S. Nonparametric statistics for the behavioural sciences. New York: McGraw-Hill, 1956

22 Booker H R. Relative comprehensibility of pictorial information and printed words in proceduralized instructions. Hum Factors 1975; 17: 266-77.

23 Hamilton E A. Graphic design for the computer age. New York: Rheinhold, 1970; 147.

24 Davis K. Hopkins J O. Readability of employee handbooks. Personnel Psychol 1950; 3: 317-26.

25 Farr $\mathbf{J}$ N. Readability and interest values in an employee handbook. J Appl Psychol 1950; 34: 16-21.

26 Carlucci $\mathrm{C}$. How readable are employee handbooks? Personnel Psychol 1951; 4: 383-95.

27 Faison E W J. Readability of children's textbooks. J Educ Psychol 1951; 42: 43-51.

28 Ogdon D P. Flesch counts of eight current texts for introductory psychology. Am Psychol 1954; 9: 143-4.

29 Anderson W. Readability of readers. Am Psychol 1956; 11: 147-8.

30 Ley P, Goldman M M, Bradshaw P W, Kincey J A, Walker C M. The comprehensibility of some $x$-ray leaflets. J Inst Health Educ 1972; 10: 47-55.

31 Grennan D M, Taylor S, Palmer D G. Doctor-patient communication in patients with arthritis. NZ Med J 1978; 88: 431-4.

32 Anderson J L, Dodman S, Kopelman M, Fleming A. Patient information recall in a rheumatology clinic. Rheumatol Rehabil 1979; 18: 18-22.

33 Gilbert J G, Levee R F. Patterns of declining memory. J Gerontol 1971; 26: 70-5.

34 Bromley D B. The psychology of human ageing. Pelican 2nd ed. Harmondsworth: Penguin, 1974.

35 Birren J E, Morrison D F. Analysis of the WAIS subtests in relation to age and education. J Gerontol 1961; 16: 363-9. 